\title{
Comparative analysis of students enrolled in administrative and IT study areas in the TecNM tutoring program in the Comarca Lagunera
}

\section{Análisis comparativo de los estudiantes inscritos en áreas de estudio administrativas e informáticas en el programa de tutorías del TecNM en la Comarca Lagunera}

\author{
MORENO-NÚÑEZ, Elda †*, ARZOLA-MONREAL, Juan Martín, FLORES-LUÉVANOS, María \\ Guadalupe and RODRÍGUEZ-LOZANO, Karla Verónica
}

Tecnológico Nacional de México Campus Lerdo / Instituto Tecnológico Superior de Lerdo

ID $1^{\text {st }}$ Author: Elda, Moreno-Núñez / ORC ID: 0000-0002-5912-082, CVU CONACYT ID: 654015

ID $2^{\text {st }}$ Co-author: Juan Martín, Arzola-Monreal / ORC ID: 0000-0002-5829-7818, CVU CONACYT ID: 428245

ID $2^{\text {nd }}$ Co-author: María Guadalupe, Flores-Luévanos / ORC ID: 0000-0003-2613-1431, CVU CONACYT ID: 450310

ID $3^{\text {rd }}$ Co-author: Karla Verónica, Rodríguez-Lozano / ORC ID: 0000-0003-2832-4165, CVU CONACYT ID: 355351

DOI: $10.35429 / \mathrm{JHS} .2021 .13 .5 .13 .19$

Received January 10, 2021, Accepted, March 30, 2021

\begin{abstract}
The object of this research was the comparative analysis of the students assisted by the Institutional Tutoring Program (PIT) of the Tecnologico Nacional de Mexico and who are enrolled in different academic engineering studies. The research was done in three technological institutes in the Comarca Lagunera. A comparative study with t-test was carried out between the administrative and IT study areas, with a confidence level of $97 \%$. Among the findings, it is worth noting that the tutored students of administrative careers are more sociable than their peers in the IT area, but these students have more confidence in their tutor to talk about their personal problems; students who use institutional support services perceive that their participation in the tutorial program improves their grades, they ask their tutor for help and are more willing to listen to his advice and recommendations. Regarding the type of family, students who live in families with both parents are more daring than those who come from another family type.
\end{abstract}

Comparative analysis, TecNM, PIT

\begin{abstract}
Resumen
El objeto de esta investigación fue el análisis comparativo de los estudiantes asistidos por el Programa Institucional de Tutoría (PIT) del Tecnológico Nacional de México y que se encuentran matriculados en diferentes estudios académicos de ingeniería. La investigación se realizó en tres institutos tecnológicos de la Comarca Lagunera. Se realizó un estudio comparativo con prueba $\mathrm{t}$ entre las áreas de estudio administrativa e informática, con un nivel de confianza del $97 \%$. Entre los hallazgos destaca que los estudiantes tutorados de las carreras administrativas son más sociables que sus compañeros del área de TI, pero éstos tienen más confianza en su tutor para platicar de sus problemas personales; los estudiantes que utilizan los servicios de apoyo institucional perciben que su participación en el programa de tutoría mejora sus calificaciones, piden ayuda a su tutor y están más dispuestos a escuchar sus consejos y recomendaciones. En cuanto al tipo de familia, los alumnos que viven en familias con ambos padres son más atrevidos que los que proceden de otro tipo de familia.
\end{abstract}

Análisis comparativo, TecNM, PIT

Citation: MORENO-NÚÑEZ, Elda, ARZOLA-MONREAL, Juan Martín, FLORES-LUÉVANOS, María Guadalupe and RODRÍGUEZ-LOZANO, Karla Verónica. Comparative analysis of students enrolled in administrative and IT study areas in the TecNM tutoring program in the Comarca Lagunera. Journal High School. 2021. 5-13: 13-19

\footnotetext{
* Author Correspondence (e-mail: elda.mn@itslerdo.edu.mx)

$\dagger$ Researcher contributing as first author
} 


\section{Introduction}

For the Asociacion Nacional de Universidades e Instituciones de Educación Superior (ANUIES), tutoring consists of the support of students in their learning stage, by capable teachers. The association proposes that an institutional tutoring system is a set of measures aimed at meeting the individual needs of the student, in addition to another group of activities that assist the tutorial practice.

The purpose of the figure of a tutor is to facilitate the tutored student's integration into the institution and undergraduate academic life and to offer timely attention to the problems that may arise in their school years, so the tutor must be prepared to forward the student to the areas where they can receive timely attention, whether preventive or remedial.

The hypothesis that guides the study is that there is a difference in the personal, family, and academic aspects of the tutored students who belong to different careers of the institution and that these psychosocial traits affect their participation in the institutional tutoring program.

\section{Methodology}

This research is quantitative and comparative in scope; the study design is non-experimental, cross-sectional and field-based.

The complex variables are the psychosocial aspects of the student: family, personality, and study habits. Each complex variable is broken down into its component elements, obtaining the simple variables. The tutoring variable refers to the set of traits and duties that the student who is participating as a tutored in the Institutional Tutoring Program implemented by the TecNM must present; the family variable includes the aspects concerning the type of relationship generated in the family context; the personality variable covers representative characteristics of the student's personality traits and self-esteem and motivation; finally, the habits one encompasses a set of practices and techniques related to study.

\section{Population and Sample}

The population of interest is the students enrolled in academic programs of administrative and computer engineering, in the institutional tutoring program of the TecNM in the Comarca Lagunera. The following schools were considered: Instituto Tecnológico Superior de Lerdo (ITSL), Instituto Tecnológico de Torreón (ITT) and the Instituto Tecnológico Superior de San Pedro. The study areas are Engineering in Business Management and Administration, Informatics Engineering and Computer Systems. In August 2017, the population size was 600 students.

Stratified sampling was selected, the strata are the two types of academic programs already mentioned. Once the strata were identified, the data collection instrument was randomly applied, to 256 students.

The strata are homogeneous because the inclusion criterion is that they belong to the onsite school system in one of the technical institutes of the study and that they are enrolled in the PIT, in any of those study areas. As shown in graph 1.

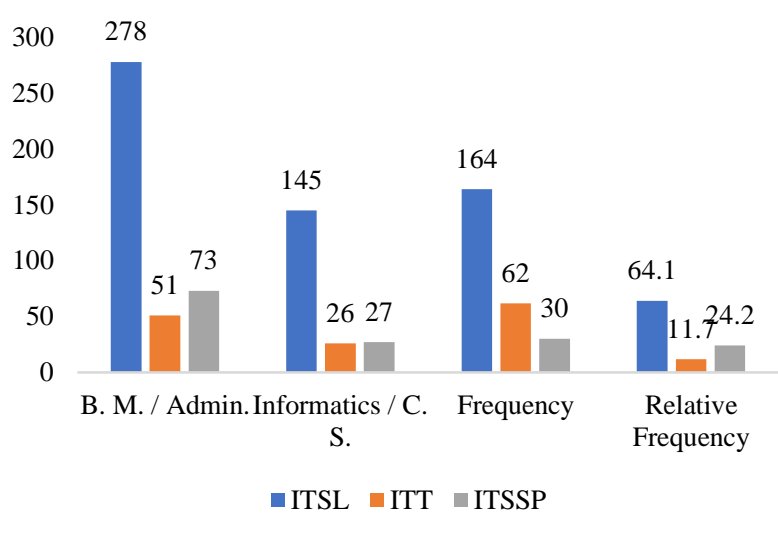

Graph 1 Strata and frequencies by Technological Institute

Another nominal variable used to characterize the sample is the academic average of the tutored students who responded to the survey, that data is shown in graph 2 . It is observed that most of the respondents have an average between 81 and 90 . 


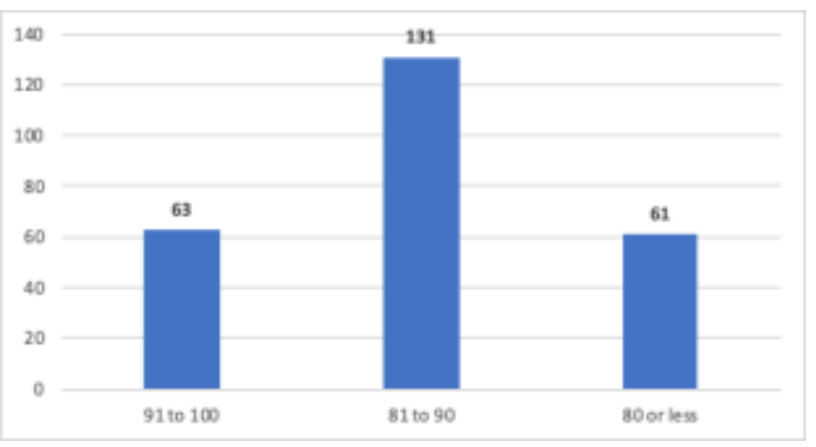

Graph 2 Frequencies of the average

The sample of students was also classified by the type of their family, the frequencies for each of the types are presented in graph 3.

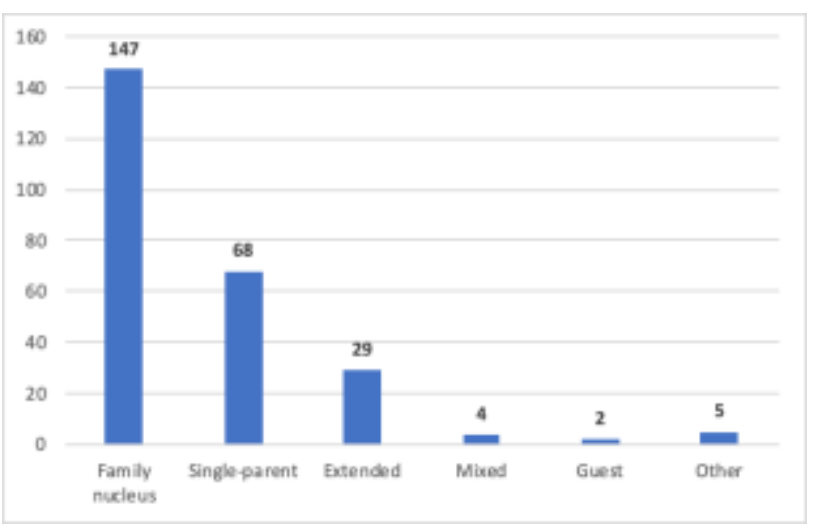

Graph 3 Frequency distribution by type of family

\section{Analysis of the Data Obtained}

After data collection, the responses obtained to the nominal and ordinal variables of the survey were captured in an Excel spreadsheet and imported into Statistica software for comparative analysis.

According to Jordi Cais (2002), comparative analysis in the study of variables is carried out to formulate broad generalizations about societies and to reach the verification of hypotheses derived from theories concerning relationships between characteristics of the social units of measurement. Using this method, experimental rigor is sought through statistical manipulation.

The comparative method is an application of the general rule of inductive logic; it consists of varying the circumstances of a phenomenon to eliminate variables and factors considered subordinate to arrive at those that are constant and fundamental.
A comparative analysis was done between the administrative and information technology areas of study, for which two groups were separated for the nominal variable area. Comparisons were also made for the nominal variable "used", which classifies the tutored students according to whether or not they have used some support service of the institution; for the categorical variable "forwarded" to compare the students who have been sent by their tutor to some support service with those who have not been forwarded; and finally with the nominal variable "family", to compare the types of family. The significance level established for the comparative analysis is 0.03 , which represents a confidence level of $97 \%$.

\section{Results}

This chapter presents the results obtained in each of the statistical analyses to which the data collected in the sample were subjected. The results are shown in the form of tables and the statistical reading of each table is included.

\section{Comparison with t-test.}

A comparative study with a t-test was carried out between the administrative and computer areas of study, for which two groups were formed. In the nominal variable "area", group 1 consisted the careers of Engineering in Administration and Engineering in Business Management; and in group 2 the field of Engineering in informatics and computer systems were classified.

The significance level established for the t-test is 0.03 . The results obtained from this comparison are shown in the table 1. (annexes). The number of valid cases per variable for the administrative area is 146 and the number of valid cases per variable for the computer area is 110. Table 1 shows that the tutors of the administrative area comply with the activities requested by their educational institution, to a greater extent than their Computer Systems peers.

Respondents from administrative fields are more sociable than their peers in the computing area and they state that they would like to work talking to people, and enjoy the company of others by participating in associations, clubs, committees, sports or cultural groups. 
Engineering students in administrative areas use a louder voice and are more comfortable speaking in public; they assume responsibilities more easily and make a greater effort to improve. They like to be questioned by the professor in class more than those in the computer science field. They use the following study techniques to a greater extent: summaries of topics prior to the evaluation and underlining, in comparison with their peers in IT study areas.

In another comparison -see table 2 in the annexes- it can be seen that the students who have used some institutional support service, are more likely to look for tutorial help when they need it or are seeking to clarify doubts about their career expectations than those who have not used the support instances.

They also stated that, if they had difficulties with a classmate or teacher, they would confide in their tutor, since they feel that he/she understands them in the situations they share with him/her, in comparison with those who have not used a support service.

Those who have used a tutor perceive that their participation in the tutorial program has improved their grades to a greater extent than those who have not used any support service. The tutored students who have not used the institution's support services take actions based on their feelings more than those who have used these services.

Another comparison made using the Ttest was that the nominal variable "forwarded" classifies the tutored students into two groups: those who have been referred by their tutor to some support service, and those who have not. The coding assigned is numeric value 1 for those who have been referred and numeric value 2 for those who have not.

The significance level established for this $\mathrm{t}$-test is 0.01 . The results obtained are shown in Table 3 in annexes. The students who have been referred to a support service are turn more to their tutor for help and are likely to confide their problems with teachers; they are also more willing to listen to advice and recommendations and perceive their tutors as empathetic and interested in them, easily reachable and who plan their tutoring sessions to a greater extent than those who have not been referred to a support service.
They also express that they enjoy working with manual tools and that their participation in the tutorial program has improved their grades and facilitated their integration into their university, to a greater extent than those who have not been referred by the tutor to support services.

A fourth comparison with the T-test was made for the nominal variable "family", which classifies the tutored students according to their family type. The coding assigned is value 1 for the nucleus family, composed of mom and dad, the respondent, and siblings, if applicable. And the value 2 , for the other types of family, is different from the nucleus family.

The significance level established for the t-test is 0.02 . The results obtained from this comparison are shown in Table 4 in annexes.

Students who come from families in which both parents are present are more willing to take risks than those who live in another type of family since they do more daring things just for the fun of doing so. They also have more stable traits, as they are able to remain calm even in critical situations, and they show a greater preference for activities that require physical effort than students whose environment is not a family nucleus.

\section{Annexes}

\begin{tabular}{|c|c|c|c|c|}
\hline Variable & $\begin{array}{l}\text { Admin } \\
\text { area }\end{array}$ & IT area & T-value & $\mathbf{p}$ \\
\hline & Mean & Mean & & \\
\hline $\begin{array}{l}\text { Performs activities } \\
\text { requested by the IT }\end{array}$ & 87.32 & 78.19 & 3.18 & 0.0017 \\
\hline $\begin{array}{l}\text { Informs your tutor } \\
\text { of your grades }\end{array}$ & 55.80 & 80.83 & -5.38 & 0.0000 \\
\hline $\begin{array}{l}\text { Confides personal } \\
\text { issues to the tutor }\end{array}$ & 38.73 & 50.97 & -2.48 & 0.0137 \\
\hline $\begin{array}{l}\text { Likes to be } \\
\text { questioned by the } \\
\text { teacher in class }\end{array}$ & 64.14 & 53.60 & 2.40 & 0.0173 \\
\hline $\begin{array}{l}\text { Enjoys the } \\
\text { company of others }\end{array}$ & 57.72 & 40.25 & 3.62 & 0.0004 \\
\hline $\begin{array}{l}\text { Oriented to } \\
\text { working with } \\
\text { people }\end{array}$ & 78.79 & 62.08 & 4.25 & 0.0000 \\
\hline Speaks loudly & 62.60 & 53.48 & 2.19 & 0.0296 \\
\hline $\begin{array}{l}\text { Ease to speak in } \\
\text { public }\end{array}$ & 68.70 & 56.61 & 2.99 & 0.0031 \\
\hline $\begin{array}{l}\text { Eager to taking } \\
\text { responsibility }\end{array}$ & 70.40 & 62.64 & 2.20 & 0.0289 \\
\hline Strives to improve & 94.79 & 87.16 & 3.89 & 0.0001 \\
\hline $\begin{array}{l}\text { Summarizes before } \\
\text { evaluation }\end{array}$ & 60.10 & 46.29 & 2.88 & 0.0044 \\
\hline $\begin{array}{l}\text { Underlines ideas } \\
\text { from texts }\end{array}$ & 65.95 & 55.10 & 2.37 & 0.0185 \\
\hline
\end{tabular}

Table 1 T-test in relation to the study area Source: own elaboration 


\begin{tabular}{|c|c|c|c|c|c|c|}
\hline Variable & Yes & No & $\begin{array}{l}\text { T- } \\
\text { value }\end{array}$ & $\mathbf{p}$ & $\begin{array}{l}\text { Valid } \\
\text { cases }\end{array}$ & $\begin{array}{l}\text { Valid } \\
\text { cases }\end{array}$ \\
\hline & Mean & Mean & & & $\begin{array}{l}\text { Group } \\
1\end{array}$ & Group 2 \\
\hline $\begin{array}{l}\text { Look to the } \\
\text { tutor when } \\
\text { needed }\end{array}$ & 72.40 & 61.16 & 2.36 & 0.0188 & 96 & 158 \\
\hline $\begin{array}{l}\text { Clarify } \\
\text { expectations }\end{array}$ & 81.08 & 69.11 & 2.82 & 0.0051 & 96 & 158 \\
\hline $\begin{array}{l}\text { Confides } \\
\text { difficulties } \\
\text { with peers }\end{array}$ & 78.31 & 64.27 & 2.96 & \begin{tabular}{|l|l|}
0.0034 \\
\end{tabular} & 96 & 158 \\
\hline $\begin{array}{l}\text { Confides } \\
\text { difficulties } \\
\text { with } \\
\text { teachers }\end{array}$ & 86.97 & 76.46 & 2.71 & 0.0072 & 96 & 158 \\
\hline $\begin{array}{l}\text { Acts as } \\
\text { he/she feels }\end{array}$ & 55.01 & 66.17 & -2.55 & 0.0112 & 96 & 158 \\
\hline $\begin{array}{l}\text { Feels tutor's } \\
\text { empathy }\end{array}$ & 67.55 & 55.38 & 2.47 & 0.0141 & 96 & 158 \\
\hline $\begin{array}{l}\text { Improves } \\
\text { grades }\end{array}$ & 71.25 & 59.85 & 2.42 & 0.0162 & 96 & 158 \\
\hline
\end{tabular}

Table 2 T-test in relation to the use of institutional support services

Source: Own Elaboration

\begin{tabular}{|c|c|c|c|c|c|c|}
\hline Variable & $\begin{array}{c}1 . \\
\text { Yes } \\
\text { Mean }\end{array}$ & $\begin{array}{l}\text { 2. No } \\
\text { Mean }\end{array}$ & $\begin{array}{c}\text { T- } \\
\text { value }\end{array}$ & $\mathbf{p}$ & $\begin{array}{l}\text { Valid } \\
\text { cases } \\
\text { Group } \\
1 \\
\end{array}$ & \begin{tabular}{|r|}
$\begin{array}{l}\text { Valid } \\
\text { cases }\end{array}$ \\
Group 2
\end{tabular} \\
\hline $\begin{array}{l}\text { Look to the } \\
\text { tutor when } \\
\text { needed }\end{array}$ & 72.15 & 59.68 & 2.68 & 0.0079 & 107 & 145 \\
\hline $\begin{array}{l}\text { Confides } \\
\text { problems } \\
\text { with } \\
\text { teachers }\end{array}$ & 86.36 & 75.65 & 2.79 & \begin{tabular}{|l|l}
0.0057 \\
\end{tabular} & 107 & 145 \\
\hline $\begin{array}{ll}\text { Would } & \\
\text { listen } & \text { to } \\
\text { tutor's } & \\
\text { advice } & \end{array}$ & 91.39 & 80.97 & 3.67 & 0.0003 & 107 & 145 \\
\hline $\begin{array}{l}\text { Manual } \\
\text { dexterity } \\
\text { with tools }\end{array}$ & 78.21 & 67.92 & 3.25 & 0.0013 & 107 & 145 \\
\hline $\begin{array}{l}\text { Tutor } \\
\text { empathy }\end{array}$ & 70.23 & 51.59 & 3.89 & \begin{tabular}{|l|}
0.0001 \\
\end{tabular} & 107 & 145 \\
\hline $\begin{array}{l}\text { Tutor } \\
\text { sincerity }\end{array}$ & 90.94 & 82.50 & 2.74 & 0.0065 & 107 & 145 \\
\hline $\begin{array}{l}\text { Tutor } \\
\text { interest }\end{array}$ & 88.83 & 76.45 & 3.78 & 0.0002 & 107 & 145 \\
\hline $\begin{array}{l}\text { Tutor } \\
\text { availability }\end{array}$ & 86.52 & 76.18 & 3.03 & 0.0027 & 107 & 145 \\
\hline $\begin{array}{l}\text { Tutor } \\
\text { planning }\end{array}$ & 92.67 & \begin{tabular}{|l|}
83.77 \\
\end{tabular} & 3.12 & \begin{tabular}{|l}
0.0020 \\
\end{tabular} & 107 & 145 \\
\hline $\begin{array}{l}\text { Improved } \\
\text { grades }\end{array}$ & 73.61 & 56.78 & 3.70 & 0.0003 & 107 & 145 \\
\hline $\begin{array}{l}\text { Integration } \\
\text { into your } \\
\text { university }\end{array}$ & 80.37 & 69.35 & 2.73 & \begin{tabular}{|l|l}
0.0067 \\
\end{tabular} & 107 & 145 \\
\hline
\end{tabular}

Table 3 T-test for the "forwarded" variable. Source: Own Elaboration

\begin{tabular}{|c|c|c|c|c|c|c|}
\hline Variable & $\begin{array}{l}\text { 1. family } \\
\text { nucleus }\end{array}$ & $\begin{array}{c}2 . \\
\text { Other }\end{array}$ & T-value & $\mathbf{p}$ & $\begin{array}{l}\text { Valid } \\
\text { cases }\end{array}$ & $\begin{array}{l}\text { Valid } \\
\text { cases }\end{array}$ \\
\hline & Media & Media & & & $\begin{array}{l}\text { Group } \\
1\end{array}$ & $\begin{array}{l}\text { Group } \\
2\end{array}$ \\
\hline $\begin{array}{l}\text { Daring } \\
\text { person }\end{array}$ & 70.92 & 59.68 & 2.54 & 0.0117 & 147 & 108 \\
\hline \begin{tabular}{|l|} 
Keep calm \\
\end{tabular} & 76.56 & 65.82 & 2.99 & 0.0031 & 147 & 108 \\
\hline $\begin{array}{l}\text { Likes } \\
\text { physical } \\
\text { effort }\end{array}$ & 64.66 & 54.99 & 2.44 & 0.0154 & 147 & 108 \\
\hline
\end{tabular}

Table $4 \mathrm{~T}$-test concerning the family type Source: Own Elaboration

\section{Conclusions}

This chapter presents the inferences derived from the results obtained.

The objective of the study is the comparison of the profile of the tutored students of the careers studied, enrolled in the Institutional Tutoring Program. Based on the results of the statistical analysis, the following is inferred:

Students in the business management and administration engineering careers have a more extroverted profile, so they have more developed social skills and are more willing to get involved in activities of any type requested by the institution.

In contrast, those in computer systems engineering and computer science correspond to a more introverted profile, prefer one-to-one relationships, are more reflective and aware of their personal and academic problems, so they trust their tutor with their grades and personal problems to a greater extent than those in careers with an administrative focus.

The Tecnológico Nacional de México states that the computer systems and informatics engineers perform their professional activities using software and hardware, mathematical and technological tools. In contrast, the main activities of the administration and business management engineers include integrating, directing, and developing work teams for the continuous improvement and integral growth of organizations, as well as promoting the development of human capital. The results obtained show a certain congruence between the student's profile and the profile expected of the graduated professional. 
It is important to analyze and establish an entrance profile for each of the careers offered in the technological institutes since in the analysis of the graduate's profile substantial differences are observed, even though they are all engineering; it would be convenient to include the application of personality tests, temperament, psychological traits, and other aspects that influence the individual's behavior, with the objective of reducing the rates of failure and desertion.

Therefore, it is recommended to design and apply a set of psychological tests with emphasis on personality, to applicants to enter any engineering program. This is not currently done in any institute of the Tecnológico Nacional de México, while in other universities in the region this procedure is carried out as part of the admission process.

\section{Thanks}

Thanks to the organizing committee of the 6th. CIERMMI 2021 Congress for the publication of this article; as well as the technological institutes that collaborated in the investigation.

\section{References}

ANUIES (2010). Programas Institucionales de Tutoría. Una propuesta de La ANUIES para su Organización y Funcionamiento en las Instituciones de Educación Superior. http://publicaciones.anuies.mx/pdfs/libros/Libro 225.pdf

Badillo, J. (2007). La Tutoría como Estrategia Viable De Mejoramiento de la Calidad de la Educación Superior. Reflexiones en torno al Curso. Revista De Investigación Educativa, 5. http://www.uv.mx/cpue/num5/practica/badillo_ tutoria.htm.

Boeree, C. G. (1997). Personality Theories Carl Jung 1875-1961. http://www.newriver.edu/images/stories/library/ Stennett_Psychology_Articles/Carl_Jung_1875 -1961_Personality_Theories.pdf.

Cais, J. (2002). Metodología del análisis comparativo, Cuadernos Metodológicos, Madrid: CIS, (Vol. 21).
Cano G. R. (2009). Tutoría universitaria y aprendizaje por competencias ¿Cómo lograrlo? Revista Electrónica Interuniversitaria de Formación del Profesorado, 12 (1), 181-204. http://www.redalyc.org/pdf/2170/21701533201 4.pdf

Castaño, E., Blanco, A. \& Asensio, E. (2012). Competencias para la Tutoría: Experiencia de Formación Con Profesores Universitarios. REDU. Revista De Docencia Universitaria, 10(2), 193-210. Recuperado de http://web.b.ebscohost.com/ehost/pdfviewer/pdf viewer?vid $=0 \&$ sid $=4 \mathrm{~b} 4224 \mathrm{f0}-172 \mathrm{a}-4 \mathrm{a} 01-9952-$ $45 \mathrm{c} 674 \mathrm{c} 18160 \% 40$ sessionmgr 101

Cattell, R. B., Eber, H. \& Tatsuoka, M. M. (1980). Cuestionario de 16 factores de la personalidad: manual. México: Manual Moderno.

DGEST (2013) Manual del Tutor. México: Dirección General De Educación Superior Tecnológica.

Espinal, I., Gimeno, A., \& González, F. (2006). El enfoque sistémico en los estudios sobre la familia. Revista Internacional De Sistemas, 14, 21-34.

Esteinou, R. (2004). El surgimiento de la familia nuclear en México. Estudios de historia novohispana, 31(031).

García, B. L. (2009). La tutoría académica en educación superior: modelos, programas y aportes; el caso del Centro Universitario de Ciencias de la Salud. Guadalajara: Editorial del Centro Universitario de Ciencias de la Salud, Universidad de Guadalajara.

García, R. I., Cuevas, O., Vales, J. J. \& Cruz, I. (2012). Impacto del programa de tutoría en el desempeño académico de los alumnos del Instituto Tecnológico De Sonora. Revista electrónica de investigación educativa, 14(1), 106-121. Recuperado de http://redie.uabc.mx/vol14no1/contenidogarciaetal.html.

Hernández S. R., Fernández C. C., \& Baptista L. P. (2014). Metodología de la Investigación (sexta ed.) México: McGraw Hill. 
López L.S. (2002). El FACES II en la evaluación de la cohesión y la adaptabilidad familiar. Psicothema. 159-166.

Núñez, J. C. (2009). Motivación, aprendizaje y rendimiento académico. $\mathrm{X}$ Congresso Internacional Galego-Português De Psicopedagogia. Braga, Portugal.

Papalia D. E., Wendkos O. S. \& Duskin F. R. (2010). Desarrollo humano. México: Mc Graw Hill.

Rogers, C. R. (2006). El proceso de convertirse en persona: mi técnica terapéutica. México: Paidós.

Romo L.A. (2005). La incorporación de los programas de tutoría en las instituciones de educación superior, México: ANUIES.

Romo L.A. (2011). La tutoría. Una estrategia innovadora en el marco de los programas de atención a estudiantes, México: ANUIES.

Thomas, E. L., \& Robinson, H. A. (1972). Improving reading in every class: a source-book for teachers. Boston: Allyn And Bacon

Thurstone, L. L. (1981). Inventario de rasgos temperamentales. México: Manual Moderno.

UNESCO (1998). Declaración mundial sobre la educación superior en el siglo XXI: Visión y Acción.

http://www.unesco.org/education/educprog/wch e/declaration_spa.htm

Valle, A., Regueiro, B., Rodríguez, S., Piñeiro, I., Freire, C., Ferradás, M., \& Suárez, N. (2015). Perfiles motivacionales como combinación de expectativas de autoeficacia y metas académicas en estudiantes universitarios. European Journal Of Education And Psychology, 8(1), 1-8.

Zabalza, M.A. (2003) Competencias docentes del profesorado universitario. Calidad y desarrollo profesional. Madrid: Narcea, S.A. de Ediciones. 